\title{
Evaluation of Student's Attitude Toward Science in Indonesia
}

\author{
A. Astalini, Dwi A. Kurniawan, Nugroho Kurniawan \& Lika Anggraini \\ Physics Education, Jambi University, Jambi, INDONESIA
}

Received 17 December 2018 • Revised 15 February 2019 • Accepted 13 March 2019

\begin{abstract}
Purpose: Attitude is expression or response of students regarding learning. Attitudes in the form of expressions of like, dislike or rejecting an object. The purpose of this research is to describe the attitudes of students towards the three attitude indicators at middle school in Jambi Province Indonesia. Research Methods: Type of research is survey research. The research instrument was in the form of a questionnaire consisting of three indicators with 27 statements and also interviews. The number of students in research samples is 2,815 which are middle school students in Jambi Province, Indonesia Regency. Results: The results of research on three dominant attitude indicators are in the good category. Adoption of scientific attitudes shows a good category with a percentage of $58.4 \%$. The pleasure of learning science is categorized as good with a percentage of $66.3 \%$. Whereas a career in science is categorized as sufficient with a percentage of $41.8 \%$.
\end{abstract}

Keywords: attitudes, science, middle school, Jambi Province.

\section{Introduction}

According to RI Law No. 20 of 2003, middle School is one of the basic education levels. At the junior high school level there are several subjects that are integrated from the disciplines of the branches of natural and social sciences. One of them is science subjects, science in junior high school are an integration of the natural sciences or science in them. Doyan, Taufik and Anjani (2018) state that "natural science or science is a collection of allied sciences that try to explain every phenomenon that occurs in nature". Generally science lessons in junior high school are taught by a science teacher. Science teachers are responsible for the continuity of learning and teaching activities and measuring student attitudes. Through student participation, professional learning facilitators are in secondary schools (Pringle, Mesa \& Hayes, 2017).

Evaluation of learning and teaching processes of science in each class can be measured by attitudes towards science. The attitude is an important, because the teacher can know each student responds to science learning with an indication that students reject or accept science learning. In school, the word "attitude" more often refers to academic field of students (Ali, Iqbal \& Saeed Akhtar, 2013). Attitudes are interpreted as an ability to give an assessment of something, which brings itself according to judgment and is reflected in attitude of accepting, rejecting, or ignoring (Dimyati \& Mudjiono, 2006). Students' attitudes toward science learning in heterogeneous groups are not influenced by different backgrounds and cultures (Narmadha \& Chamundeswari, 2013). Liaghatdar, Soltani and Abedi (2011) consider attitude toward science as

(C) Authors. Terms and conditions of Creative Commons Attribution 4.0 International (CC BY 4.0) apply. Correspondence: Dwi A. Kurniawan, Physics Education, Jambi University, Jambi, INDONESIA. E-mail: dwiagus.k@unja.ac.id. 
important, because attitudes can influence the achievements and performance of students very well.

Pamungkas, Subali \& Lunuwih (2017) consider that natural science education is an effort or process to give knowledge to students about the nature of science. Science has been introduced from basic education, science is a learning process and continues (Narmadha \& Chamundeswari, 2013). In middle school, first students consider science as the difficult subject. Science education researchers have initiated the argument that students still find it difficult to learn science concepts (Topcu \& Sahin-Pekmez, 2009). Student's attitude towards science is seen from how they respond to science lessons. In general, attitudes towards science are divided into negative and positive attitudes. Students' positive attitudes in learning are characterized by being more diligent in learning so that they get satisfactory results (Rijal \& Bachtiar, 2015). Negative attitude is an attitude that inhibits student learning activities, according to Nursa'adah (2014). The causes of students' negative views and attitude toward teaching of science because the traditional methods of teaching science which are used continuously, for example, learning takes place passively, and students are reluctant to think, and accept delivered material. Therefore from this explanation, the purpose of science learning is to foster a positive attitude toward students in science (Sofiani et al., 2017). Attitudes toward science measured in this research were seen through three indicators adopted from Fraser (1981), namely adoption of scientific attitudes, enjoyment in learning science, and career interest in science.

The scientific attitude in science has been taught early through the discovery of existing concepts. Parents often link scientific concepts to familiar examples (although sometimes inaccurately) and discuss complex scientific ideas (Alexander, Johnson \& Kelley, 2012). Science is not lesson that focuses on theoretical explanations because it is likely that will be many differences in opinion according to individual observations that require direct practice. Science is one of lessons aimed at developing knowledge and doing, so that students able to gain in-depth understanding of the environment, one of the functions and objectives of science learning is that students gain experience as the application of scientific methods through experiments so students can be trained in scientific attitude (Istikomah, Hendratto \& Bambang, 2010). Lee (2018) states that perception or misperception about science mediates the relationship between knowledge and attitudes (scientific knowledge $\rightarrow$ perceptions of science $\rightarrow$ attitudes of science). Scientific attitude is one indicator of the positive attitudes towards science in students. Attitudes towards science and scientific attitudes are two inseparable elements. Synergy from the development of scientific attitudes can realize for student the ability to gain scientific knowledge about science in life. So it is important to look at the level of scientific attitudes and the attitude of teaching science for teachers to guide the scientific talent of each student (Erdogan, 2017). Lacap (2015) states that "scientific attitude plays a major role in students pursuing science education".

Enjoyment in learning is emotion of expression of students intrinsically linked to student motivation to understand, with learning and school performance at school (Manasia, 2015). The pleasure of learning science can be defined that every student who has positive attitude in science must feel and have the comfort and pleasure to learn science. "Students assess their 'pleasure' from activities (hate, dislike, indifference, love), while the teacher assesses the 'usefulness' of each activity" (Maharaj-Sharma \& Sharma, 2017), so that student enjoyment during the science learning process is seen from students responding to the learning, in general, and the indicators of pleasure in learning science are expressed with pleasure or not pleasure and like or dislike. A happy or like attitude of each student will deduce the pleasure of students towards science, while the attitude of displeasure or dislike will conclude students to displeasure with science. The students' enjoy attitude in science can be shown how students are open and enthusiastic about science subjects inside or outside the classroom, which express students' sincere interest in learning and doing science assignments.

The skills to make decisions in a career are important for every student because 
students are required to have maturity in their career choices (Zamroni, 2016). Career interest in science can be defined that every student in the future has an interest in a career or continuing his education in the field of science. An interest in a career in science is an important task for every parent to support. Halim et al. (2017) state that the positive perceptions and values of parents toward the subject of science propel parents to cultivate their children's interest in science and science-related careers. Encouraging students to pursue a career or continue their studies of science is very important now. Natural sciences is very important in everyday life to meet human needs in solving problems and the application of science is done wisely to maintain environmental sustainability (Rohmawati, 2012).

The purpose of the study was to find out how is the attitude of junior high school students to the science subjects and how was effective the three indicators to be able to improve students' attitudes towards science in junior high school in Jambi province. In this study the research questions are the following:

(1) How are student attitudes viewed from the adoption of scientific attitudes?

(2) What is the student's attitude towards pleasure in learning science?

(3) How is the attitude of students in their interest in a career in science?

(4) What are the obstacles to the adoption of scientific attitudes, pleasure in learning science and the interest in a career in the field of science?

The results of this study can also contribute to further research for the schools that we studied so that teachers in the schools are able to improve students' attitudes in learning science.

\section{Research methodology}

This study uses survey research. Survey research examines large populations by selecting and reviewing selected samples from the population (Kerlinger, 2014). According to Creswell (2017) "from this sample, researchers generalize or make claims about that population". This research was conducted in Jambi Province. The implementation of this research was conducted in April-May 2018. The research subjects were all seventh and eighth-grade students at the junior high school level in Jambi Province. This study uses a total sampling technique. The total number of junior high school students studied was 2,815 students, consisting of 1,255 male students and 1,560 female students. Data collection is done through the provision of research instruments in the form of questionnaires. This questionnaire has 27 statement of attitude, which is divided into 14 positive statements and 13 negative statements. The dimensions of student attitudes towards the science subjects studied are based on predetermined indicators, namely adoption of scientific attitudes, enjoyment of science lessons, and interest in a career in science/career science (career interest in science). The attitude of students towards science subjects in the study was measured using a Likert scale. This questionnaire data are given to students of class VII and VIII SMP in Jambi Province Indonesia. This research data are in the form of quantitative data and analyzed using descriptive statistics. The results of the questionnaire data are processed using SPSS software or applications. This processing aims to see the attitudes of junior high school students towards science in Jambi Province Indonesia based on predetermined attitude indicators.

\section{Results}

The use of attitude scale was in order to see student attitudes toward certain objects, and the results of attitude categories include reject (negative), support (positive), and neutral (Sudjana, 2012). The results of this data were obtained from the distribution of research questionnaires on students' attitudes towards science in junior high school students in grades 7 
and 8 in Jambi Province, total of 2,815 students (1,560 female students and 1,255 male students). The results of the attitude questionnaire data displayed in the data analysis consisted of 2 parts of the assessment. The first is an interval based assessment that has the following attitude categories: very bad, bad, enough, good, very good. Assessment of this attitude category is based on the frequency and percentage of all students who choose each attitude category. The second is based on the attitude scale, and the attitude scale used is the Likert scale which consists of 5 different ratings. This attitude scale consists of 5 ratings $(1=$ very bad, $2=$ bad, $3=$ enough, $4=$ good, $5=$ very good). This assessment is based on the number of all students who choose each attitude scale and produce mean, mode, median, and standard deviation. Both of these attitude assessments were obtained using descriptive statistical analysis of SPSS data processing software.

The results of the research data shown below are based on three indicators of attitude, namely adoption of scientific attitudes, enjoyment of science lessons, and career interest in science (career interest in science). The results of questionnaire data are based on these indicators.

\subsection{Adoption of scientific attitudes}

The following is the result of descriptive data analysis using SPSS from questionnaire data on student attitudes towards science based on the Adoption of Scientific Attitudes indicator, and it can be seen from the questionnaire results table below.

Table 1. Adoption of scientific attitude

\begin{tabular}{|c|c|c|c|c|c|c|c|c|c|}
\hline \multicolumn{3}{|c|}{ Classification } & \multirow{2}{*}{$\%$} & \multirow{2}{*}{$\begin{array}{l}\text { Standard } \\
\text { deviation }\end{array}$} & \multirow{2}{*}{ Mean } & \multirow{2}{*}{ Mode } & \multirow{2}{*}{ Median } & \multirow{2}{*}{ Min } & \multirow{2}{*}{ Max } \\
\hline Rate & Attitudes & Amount & & & & & & & \\
\hline $7.0-12.6$ & Very bad & 0 & $\mathrm{O}$ & & & & & & \\
\hline $12.7-18.2$ & $\mathrm{Bad}$ & 90 & 3.2 & & & & & & \\
\hline $18.3-23.8$ & Enough & 1080 & 38.4 & 0.691 & 3.64 & 4.0 & 4.0 & 2 & 5 \\
\hline $23.9-29.4$ & Good & 1386 & 49.2 & & & & & & \\
\hline $29.5-35.0$ & Very good & 259 & 9.2 & & & & & & \\
\hline
\end{tabular}

From the table above, student attitudes towards science are based on indicators of adoption of scientific attitudes in junior high schools, and the results of the data show that: the categories of student attitudes are very bad as much as $0 \%$ (no voters), students categorized as bad as $3.2 \%$ (90 out of 2,815 students), students with enough categories as much as $38.4 \%$ (1,080 of 2,815 students), students with good categories as much as $49.2 \%$ (1,386 of 2,815 students), and students with very good attitude as much as $9.2 \%$ ( 259 out of 2,815 students). Whereas based on the scale of the attitude shows the data obtained is the mean value of 3.64 , mode is 4 , besides that from the data analysis the standard deviation value (0.691) is smaller $(<)$ than the mean (3.64). The mean is a representation of all research data samples or shows valid research data. These results indicate that students' attitudes towards science on the indicator of scientific attitude adoption, students have a positive attitude and it is in the good category. This is supported by the results of the above data which shows that $49.2 \%$ of students, or 1,386 students from 2,815 total students, are in a good range and supported by the mode value or the dominant attitude scale chosen is 4 "good".

\subsection{Enjoyment of science lessons}

The following is the result of descriptive data analysis of students' attitudes towards science based on indicators of learning pleasure in science, and it can be seen from the table below. 
Table 2. Enjoyment in learning science

\begin{tabular}{cccccccccc}
\hline & Classifications & & \% & $\begin{array}{c}\text { Standard } \\
\text { deviation }\end{array}$ & Mean & Mode & Median & Min & Max \\
\cline { 1 - 5 } Rate & attitudes & Amount & & & & & & & \\
10.0-18.0 & Very bad & 8 & 0.3 & & & & & \\
18.1-26.0 & Bad & 106 & 3.8 & & & & & \\
$26.1-34.0$ & Enough & 835 & 29.7 & 0.78453 & 3.8014 & 4.0 & 4.0 & 1 & 5 \\
$34.1-42.0$ & Good & 1354 & 48.1 & & & & & \\
42.1-35.0 & Very good & 512 & 18.2 & & & & & \\
\hline
\end{tabular}

From the table above, the results of the assessment of students' attitudes towards science based on the indicators of Enjoyment of science lessons, show the following: the categories of student attitudes are very poor as much as $0.3 \%$ ( 8 of 2,815 students), 3.8\% is in bad categories (106 of 2,815 students), students with enough categories as much as $29.7 \%$ (835 out of 2,815 students), students with good categories as much as $48.1 \%$ (1,354 out of 2,815 students), and students who have very good attitudes as much as $18.2 \%$ (512 of 2,815 students). While based on the scale of the attitude of the results, the data obtained show that the mean value is 3.8044 , and the mode is 4 . In addition, the standard deviation value $(0.78453)$ is smaller $(<)$ than the mean (3.8044), this means that the mean value is a representation of all sample data studied or shows valid research data. These results indicate students' attitudes towards science on indicators of pleasure in learning in science showed a positive attitude to science and viewed from the results of data analysis that $48.1 \%$ of students, or 1,354 of a total of 2,815 students, were in a good category. This is also supported on the results of the attitude scale on the questionnaire that is most chosen by students is scale 4 which is "good".

\subsection{Career interest in science}

The results of the descriptive analysis of student attitudes towards science based on indicators of leisure interest in science can be seen from the results table below.

Table 3. Career interest in science

\begin{tabular}{cccccccccc}
\hline & Classification & & \% & $\begin{array}{c}\text { Standard } \\
\text { deviation }\end{array}$ & Mean & Mode & Median & Min & Max \\
\hline Renting & attitudes & amount & & & & & & & \\
1 10.0-18.0 & Very bad & 10 & 0.4 & & & & & & \\
$18.01-26.0$ & Bad & 147 & 5.2 & & & & & & \\
$26.01-34.0$ & Enough & 1176 & 41.8 & 0.77196 & 3.6 & 3.0 & 4.0 & 1 & 5 \\
$34.01-42.0$ & Good & 1164 & 41.3 & & & & & & \\
$42.01-35.0$ & Very good & 318 & 11.3 & & & & & & \\
\hline
\end{tabular}

Based on the results of data analysis, it can be explained that the table above shows the results of the assessment of students' attitudes towards science based on indicators of career interest in the field of science, with the results of the data show that students' attitude categories are not as good as $0.4 \%$ (10 of 2,815 students), students with a bad category as much as 5.2\% (147 out of 2,815 students), students with enough categories as much as $41.8 \%(1,176$ out of 2,815 students), students with good categories as much as $41.3 \%$ (1,164 of 2,815 students), and students with very good attitude as much as $11.3 \%$ (318 out of 2,815 students). While based on the scale of attitude from the results of the data above shows the data obtained is a mean value of 3.6 and mode is 3 . In addition, the value of the standard deviation (0.77196) is smaller $(<)$ than the mean 
(3.6), so the conclusion is that the mean value obtained is a representation of all sample data studied or shows that the research data is valid.

The results of questionnaire data on indicators of interest in a career in the field of science show the findings of several obstacles that lead to negative attitudes towards students. This is indicated by the attitude of students who are categorized enough (41.8\%) to have a greater value than the good category (1.34\%) or very good (6.9\%). Besides that it is supported by questionnaire data based on attitude scale, the most scale is chosen by respondents or the mode value is 3 or "sufficient", and has a mean value of 3.4451 which means that the average student answers enough.

\subsection{Obstacles to student attitudes}

The results of the measurement of 2,815 students were taken through a questionnaire. The three attitudinal indicators measured are elaborated by 27 statements, but there are still students with negative attitudes as evidenced by their disapproval of the statements given, as it is shown in the table below.

Table 4. Obstacles to student attitudes

\begin{tabular}{lc}
\hline Indicator & Obstacles \\
\hline Adoption of scientific attitudes & $3.2 \%$ \\
Fun in learning science & $4.1 \%$ \\
A career interest in science & $5.6 \%$ \\
\hline
\end{tabular}

Based on the table above there are still obstacles to the three measured attitude indicators. These results indicate that the indicator of the adoption of scientific attitudes constraints is $3.2 \%$ (90 out of 2,815 students). The pleasure indicators in science learning show obstacle values of $4.2 \%$ (114 of 2,815 students). Whereas the indicators of interest or interest in a career in the field of science show an obstacle value of $5.6 \%$ ( 157 out of 2,815 students). From these results, it can be seen that the biggest obstacle is the indicator of career interest in the field of science.

\section{Discussion}

Facts show that the attitude of students is one of the key factors in learning science (Liaghatdar, Soltani \& Abedi, 2011). An attitude is a form of expression or student response to learning objects. Attitudes such as expressions of likes or dislike, or reject or accept an object. Attitude measurement is done to see the individual's ability to object. In this study, researchers measured students' attitudes towards science as an object. The attitude "towards science" is used to indicate that individual feels and thinks about science (Sethi, 2015). The essence of attitudinal measurement is useful for knowing students' feelings during the science learning process in the form of both positive attitudes and negative attitudes, and the expectation that each student's attitude towards science is a positive attitude. Because, if students have a positive attitude towards science, it will affect abilities related to the field of science (Usta \& Akkanat, 2015). Dessele (2005) states that "the attitude scale usually consists of a collection of statements or "items" that measure the respondent's level of agreement, likes, or other similar perceptions". Measurements about student attitudes towards science have focused on what attitudes are to be measured. In this study, there are three dimensions of attitude measurement carried out, namely the adoption of scientific attitudes, pleasure in learning science and interest in increasing hours of science lessons. 


\subsection{Adoption scientific attitude}

Adoption of scientific attitudes is used to see one's willingness to assess and revise opinions based on experiments and empirical data (Farenga \& Joyce, 2010). In Table 1 reveals that the attitude of students based on scientific attitude adoption has a good category with mean 3.64 and mode 4. From the results of the mean and mode, it reveals that student attitudes toward the indicator of adoption of dominant scientific attitudes are categorized as good. Furthermore, it is also supported from the results of data analysis in Table 1 which shows that $49.3 \%$ or 1,386 of 2,815 students are in the good category and $9.2 \%$ or 259 out of 2,815 students fall into the very good category. This is supported by the results of the interview below:

Question: Do you like differences of opinion in the process of learning science? If yes, why and if not why?

Answer: Yes, I like differences of opinion, because from different opinions I can consider which opinions are the best in science learning.

From the results of interviews, the attitudes of the dominant students are good, meaning students are willing to seek their own learning experience. Adoption of attitudes will be high if the learning process uses the inquiry method (Wolf \& Freser, 2007). So that it can be concluded that the indicator of scientific attitude adoption in this study shows that students' attitudes are more dominant in good categories and show students' positive attitudes toward science are in a good category. Good attitude categories from the results of data analysis are also supported by the main factors, first students have the attitude of reading pleasure towards new things even though those that do not fit their thinking. In this line, Akpinar et al. (2009) states a more positive attitude towards science is related to a positive attitude about the usefulness of science.

\subsection{Enjoyment in science lesson}

Enjoyment is considered as an emotional variable and an important concept in learning, because it describes the problem of education to students (Mohammad-Davoudi \& Parpouchi, 2016). Enjoyment of learning in science explains the students' responses to science lessons, which are shown by the students' enjoyment of the science lesson and how strong is the students' desire to learn. From the results of observation, it shows in Table 2 the indicators of pleasure in learning science in general from the explanation of results of the dominant questionnaire data towards a positive attitude with a good category, and the mean value is 3.8. Supported also from the results of interviews conducted that students' attitudes towards SAINTS were dominant. This can be seen from the results of the interview below:

Question: Do you like science lessons in school?

Answer: Yes, I like science

Question: Why do you like science lessons?

Answer: Because science is natural science and I want to learn about natural phenomena that occur. But I don't like learning science related to calculations and formulas.

The results of the interviews conducted showed the students' attitudes towards the science subject in good categories. That is, students assume that science is one of the fun lessons. This positive attitude is proven that the average student who agrees that the science lesson is fun and is also one of the most interesting subjects. One example of student pleasure in science is that students are motivated to seek more knowledge in the field of science. Enjoyment is considered the mechanism that encourages the concentration of learners, helps the learning process, and builds the learning environment (Lucardie, 2014). 


\subsection{Career interest in science}

Interest in learning science triggers and maintains an effective component in the form of pleasure that is aligned between cognitive in class, integration, and enhancing science learning experiences (Jack \& Lin, 2018). So it can be concluded that interest or interest in a career in the field of science has a significant influence on the growth of a positive attitude. Furthermore, Table 3 shows the results of indicators of career interest in the field of science whose results are quite good which is indicated by the results of mean 3.4451 and mode 3 . Based on the results of the mean and mode it concluded that student attitudes tend to be negative. This is also supported by the results of Table 3 showing the figure of $41.8 \%$ or 1,176 of the 2,815 students in the sufficient category. The attitude of students shows a high enough category, so that concludes the negative attitude of students. This high number is supported also based on the results of data of students who have a bad attitude and are not very good with a number of $5.6 \%$. The reason is that students assume that science is a difficult lesson, which causes their low interest in a career or continuing studies in science. Reinforced by Astuti, Sunarno \& Sudarisman (2012), it is stated that "studying science in school is still a difficult lesson for some Indonesian students. The assumption that learning science is difficult, can only be done by smart students, and boring is so strongly attached to the minds of many children". Besides that it is supported by the results of interviews below:

Question: What is your response if you become a science scientist in the future?

Answer: I am quite happy to learn about SCIENCE, but I am lacking in faith or disagree if I later become a science scientist (SAINS).

Question: Do you want to become a science teacher after graduating?

Answer: yes, I think being a teacher of SAINS is quite interesting to do even though science lessons are quite difficult for me.

The results of the interview concluded that students were reluctant to pursue careers to become science scientists, and there was interest in students being science educators even though students thought science lessons as a difficult lesson. This result can be caused by students' interest that is different from one student to another. Furthermore, it is the task of educators to change new methods in science teaching in increasing students' positive attitudes towards career interests in science.

\subsection{Obstacles to student attitudes}

Overall results of the study showed a positive attitude towards the adoption of scientific attitudes, the pleasure of learning science, and an interest in a career in science. Although showing positive attitudes there are still some obstacles. Constraints on the indicator of the adoption of scientific attitudes are shown from the analysis of the results of Table 1 data, and the results of the data show $3.2 \%$ or 90 students who show negative attitudes. The reason is that students on the indicator of scientific attitude adoption have problems, if students are not interested in exploring more understanding of science around them. To increase student interest needed more students to have a nonchalant nature about the things he/she just got about science. This is expressed by being neutral and rejecting (negative) things that students get in science. This factor causes low student innovation when studying science.

Table 4 shows that the $4.1 \%$ or 114 out of 2815 students showed their dissatisfaction in science learning. The figure concludes the number of students who show negative attitudes toward the indicator of pleasure in learning science. The main factors are student displeasures when learning science, based on student learning experiences. The pleasure of learning science is related to student experience (Joyce \& Farenga, 2010). It was proven that from a number of these students disagreed about the discourse of adding the allocation of learning to science in the classroom, and 
students were not happy to wait for science lessons in the study hours, because students tended to think that science was a less interesting and boring lesson. The results of the study by Manasia (2015) show that "school is a bad period in their lives, and prevent them from doing more interesting things". So that educators need solutions to increase happy interest when learning science to students. Farenga \& Joyce (2010) state that in order "to encourage pleasure in science lessons, educators should ensure that students see science interesting through direct researchbased activities".

The indicator of interest in a career in science is an indicator of the highest percentage of obstacles, namely $5.6 \%$ or 157 students being negative. Jocz et al. (2014) state that recent research revealed that students' interest in science in schools showed a decline. Factors of high numbers are constraints on the interest in a career in science because students still have a low interest in learning science. According to Najemi and Wijayanti (2014), "in order to foster interest and interest in learning science, teachers must be brave to use innovative learning models". This school environment has an influence on the interest in a career in the field of science for each student. Furthermore, the low interest in a career in science is because students have experience in failing to learn science at school/life. The reason is that too often science instruction fails to engage students' interests and separate students from their daily experiences (Kolodner et al., 2009).

\section{Conclusions}

Based on the results and discussion, it can be seen that the indicator of adoption of scientific attitudes is relatively good, the pleasure of learning science is quite good, and the interest in a career in the field of science is also quite good. Overall, students' attitudes towards science in Jambi Province Indonesia are good. So it can be concluded that the attitude of junior high school students to science in Jambi Province Indonesia has a positive attitude. This illustrates that the acceptance of Science in the eyes of students gets a positive attention because it can optimize learning outcomes.

\section{Acknowledgements}

Researchers would like to thank the Physics Education Study Program which has supported, and provided facilities to researchers so that this research can be completed. In addition, the researchers also thanked all those who helped the researcher in this research.

Conflicts of interest: none

\section{References}

Akpinar, E., Yildiz, E., Tatar, N., \& Ergin, O. (2009). Students' attitudes toward science and technology: An investigation of gender, grade level, and academic achievement. Procedia Social and Behavioral Sciences, 1(1), 2804-2808.

Alexander, J. M., Johnson, K. E., \& Kelley, K. (2012). Longitudinal analysis of the relations between opportunities to learn about science and the development of interests related to science. Science Education, 96, 763-786.

Ali, M. S., Iqbal, A., \& Saeed Akhtar, M. M. (2013). Students' attitude towards science and its relationship with achievement score at intermediate level. Journal of Elementary Education, 25(2), 61-72. 
Astuti, R., Sunarno, W., \& Sudarisman, S. (2012). Pembelajaran Sains Dengan Pendekatan Keterampilan Proses Sains Menggunakan Metode Eksperimen Bebas Termodifikasi Dan Eksperimen Terbimbing Ditinjau Dari Sikap Ilmiah Dan Motivasi Belajar Siswa [Science learning with the science process skill approach using a modified free experiment method and a guided experiment viewed from the scientific attitude and motivation of student learning]. Jurnal INKUIRI, 51-59.

Bybee, R., McCrae, B., \& Laurie, R. (2009). PISA 2006: An assessment of scientific literacy. Journal of Research in Science Teaching, 46(8), 865-883.

Creswell, J. W. (2017). RESEARCH DESIGN: Pendekatan Metode Kualitatif, Kuantitatif, dan Campuran, Edisi Keempat [Qualitative, quantitative and mixed method approaches, Fourth Edition]. Yogyakarta: Pustaka Belajar.

Desselle, S. P. (2005). Construction, implementation, and analysis of summated rating attitude scales. American Journal of Pharmaceutical Education, 75(8), 1-11.

Dimyati, \& Mudjiono. (2006). Belajar dan Pembelajaran [Teaching and learning]. Jakarta: PT. Rineka Cipta.

Doyan, A., Taufik, M., \& Anjani, R. (2018). Pengaruh Pendekatan Multi Representasi Terhadap Hasil Belajar Fisika Ditinjau dari Motivasi Belajar Peserta Didik [Effect of multi representation approach on physics learning outcomes viewed from student motivation]. Jurnal Penelitian Pendidikan SAINS, 35-45.

Eaton, A. A., \& Visser, P. S. (2008). Attitude importance: Understanding the causes and consequences of passionately held views. Social and Personality Psychology Compass, 2, 1719-1736.

Erdogan, S. C. (2017). Science teaching attitudes and scientific attitudes of pre-service teachers of gifted students. Journal of Education and Practice, 8(6), 164-170.

Falk, J. H., Storkdieck, M., \& Dierking, L. D. (2007). Investigating public science interest and understanding: evidence for the importance of free-choice learning. Public Understanding of Science, 16, 455-469.

Farenga, S. J., \& Joyce, B. A. (2010). Science-related attitudes and science course selection: A study of highability boys and girls. In: S. J. Farenga, \& B. A. Joyce, Roeper Review (pp. 37-41). London: Routledge.

Fraser, B. J. (1981). Tosra: Test of science-related attitudes: Handbook. Australian Council for Educational Research.

Halim, L., Rahman, N. A., Zamri, R., \& Mohtar, L. (2017). The role of parents in cultivating children's interest towards science learning and careers. Journal of Sciences, 39(2), 1-7.

Istikomah, H., Hendratto, S., \& Bambang, S. (2010). Penggunaan Model Pembelajaran Group Investigation Untuk Menumbuhkan Sikap Ilmiah Siswa [Use of group investigation learning models to grow students' scientific attitudes]. Jurnal Pendidikan Fisika Indonesia, 40-43.

Jack, B. M., \& Lin, H.-s. (2018). Warning! Increases in interest without enjoyment may not be trend predictive of genuine interest in learning science. International Journal of Educational Development, 62, 136-147.

Joyce, B. A., \& Farenga, S. J. (2010). Informal science experience, attitudes, future interest in science, and gender of high-ability students: An exploratory study. School Science and Mathematics, 99(8), 431-437.

Kerlinger, F. N. (2014). Asas-Asas Penelitian Behavioral [Behavioral research principles]. Yogyakarta: Gadjah Mada University Press.

Lacap, M. P. (2015). The scientific attitudes of students major in science in the new teacher education curriculum. Asia Pacific Journal of Multidisciplinary Research, 3(5), 7-15.

Lee, S., \& Kim, S. H. (2018). Scientific knowledge and attitudes toward science in South Korea: Does knowledge lead to favorable attitudes. SAGE Journal, 1-26. 
Liaghatdar, M. J., Soltani, A., \& Abedi, A. (2011). A validity study of attitudes toward science scale among Iranian secondary school students. International Education Studies, 4(4), 36-46.

Lucardie, D. (2014). The impact of fun and enjoyment on adult's learning. Procedia - Social and Behavioral Sciences, 142, 439-446.

Maharaj-Sharma, R., \& Sharma, A. (2017). Using ICT secondary school science teaching - What students and teachers in Trinidad and Tobago say? European Journal of Education Studies, 42(10), 2501-1111.

Manasia, L. (2015). Enjoyment of learning in upper secondary education. An exploratory research. Procedia - Social and Behavioral Sciences, 180, 639-646.

Mohammad-Davoudia, A. H., \& Parpo, A. (2016). The relation between team motivation, enjoyment, and cooperation and learning results in learning area based on a team-based learning among students of Tehran University of medical science. Procedia - Social and Behavioral Sciences, 184-189.

Najemi , C., \& Wijayanti, A. (2014). Upaya Peningkatan MInat dan Prestasi Belajar Sains Siswa Kelas VIII SMP Negeri 12 Yogyakarta Tahun Pelajaran 2012/2013 Melalui Model Pembelajaran Konstruktivisme [Efforts to increase science and learning achievement of class VIII students of Yogyakarta State Middle School 12/2012 academic year through constructivism learning model]. Jurnal Pendidikan SAINS NATURAL, 1-9.

Narmadha, U., \& Chamundeswari, D. (2013). Attitude toward learning of science and academic achievement in science among students at the secondary level. Journal of Sociological Research, 2.

Nursa'adah, F. P. (2014). Pengaruh Metode Pembelajaran Dan Sikap Siswa Pada Pelajaran Sains Terhadap Hasil Belajar Sains [The influence of learning methods and attitudes of students on science lessons on science learning outcomes]. Jurnal Formatif, 112-123.

Pamungkas, A., Subali, B., \& Lunuwih, S. (2017). Implementasi Model Pembelajaran Sains Berbasis Kearifan Lokal untuk Meningkatkan kreativitas dan Hasil Belajar Siswa [Implementation of local wisdom-based science learning model to improve creativity and student learning outcomes]. Jurnal Inovasi Pendidikan SAINS, 118-127.

Pringle, P. M., Mesa, J., \& Hayes, L. (2017). Professional development for middle school. Journal of Science Teacher Education, 57-72.

Rijal, S., \& Bachtiar, S. (2015). Hubungan antara Sikap, Kemandirian Belajar, dan Gaya Belajar dengan Hasil Belajar Kognitif Siswa [Relationship between attitudes, learning independence, and learning styles with student cognitive learning outcomes]. Jurnal Bioedukatika, 15-20.

Rohmawati, A. N. (2012). Penerapan Pembelajaran Sains Terpadu Dengan Model Pembelajaran Inkuiri Pada Tema Mata Di Smp Negeri 1 Maduran Lamongan [Application of integrated science learning with learning model inquiry in eye-evidenced themes in Public High School 1 Maduran Lamongan]. Jurnal Pendidikan Sains, 76-91.

Sakariyau, A. O., Taiwo, M. O., \& Ajagbe, O. W. (2016). An investigation on secondary school students' attitude towards science in Ogun State, Nigeria. Journal of Education and Practice, $7(28), 125-$ 128.

Sethi, U. (2015). Study of attitude of the students towards science in relation to certain non-school factors. International Journal of Education and Information Studies, 75-80.

Sofiani, D., Maulida, A. S., Fadhilah, N., \& Sihite, D. Y. (2017). Gender differences in students' attitude toward science. International Conference on Mathematics and Science Education (p. 895). IOP Publishing.

Sudjana, N. (2012). Penilaian Hasil Proses Belajar Mengajar [Assessment of teaching and learning Results]. Bandung: PT Remaja Rosdakarya.

Topcu, M. S., \& Sahin-Pekmez, E. (2009). Turkish middle school students' difficulties in learning genetic concepts. Journal of Turkish Science Education, 6(2), 55-62. 
A. Astalini et al. - Evaluation of Student's Attitude Toward Science in Indonesia

Usta, E., \& Akkanat, Ç. (2015). Investigating scientific creativity level of seventh grade students. Procedia Social and Behavioral Sciences, 191, 1408-1415.

Wolf, S. J., \& Freser, B. J. (2007). Learning environment, attitudes, and achievement among middle-school science students using inquiry-based laboratory activities. Research of Science Education, 38, 321-341.

Zamroni, E. (2016). Urgensi Career Decision Making Skills dalam Penentuan Arah Peminatan Peserta Didik [The urgency of career decision making skills in determining the direction of specialization of students]. Jurnal Konseling Gusjigang, 140-152. 